\title{
Continuous midazolam infusion as treatment of status epilepticus
}

Roshan Lal Koul, Guru Raj Aithala, Alexander Chacko, Rajendra Joshi, Mussalem Seif Elbualy

\begin{abstract}
In a tertiary referral centre, midazolam infusion was tried as treatment for 20 children with status epilepticus over a period of two years. The mean age of the children was 4.07 years. Twelve children with refractory status epilepticus had received intravenous or per rectal diazepam and intravenous phenytoin/ phenobarbitone or both before midazolam was given $(0.15 \mathrm{mg} / \mathrm{kg}$ bolus followed by 1-5 $\mu \mathrm{g} / \mathrm{kg} / \mathrm{min}$ infusion). Eight children required only midazolam to control the established status epilepticus. The seizures were controlled in 19 children. The mean time required for complete cessation of seizures was 0.9 hours. The mean infusion rate required was $2.0 \mu \mathrm{g} / \mathrm{kg} / \mathrm{min}$. All children had regained full consciousness by a mean of 5.1 hours after discontinuation of midazolam treatment. No metabolic derangement or compromise of vital functions was noted in any of the children. Midazolam infusion is thus an effective and safe therapeutic approach for the management of childhood status epilepticus.

(Arch Dis Child 1997;76:445-448)
\end{abstract}

Keywords: status epilepticus; refractory; midazolam

Status epilepticus is a medical emergency that requires prompt intervention. The term is applied to situations in which seizures occur so frequently that complete recovery between fits does not take place. ${ }^{1}$ A more substantive definition is continuous seizures lasting for 30 minutes or longer or recurrent seizures occurring with impairment of consciousness between seizure activity. ${ }^{2}$ Status epilepticus is more common in childhood, and the reported death rate varies between 3 and $20 \%{ }^{3}$ Prolonged seizure activity itself produces irreversible cerebral damage, independent of accompanying hypoxia, acidosis, and consequent biochemical derangements. The excessive metabolic demands of continuously firing neurones leading to depletion of essential nutrients is currently thought to be the most important factor leading to cell death during continuous seizures. ${ }^{4}$ Although the majority of children who suffer continuous seizures respond to intravenously administered diazepam and phenytoin sodium, some require other modalities of treatment including general anaesthesia, which could lead to serious adverse effects.
Midazolam is a recently developed water soluble benzodiazepine, commonly used as a preanaesthetic agent with remarkable anticonvulsant action. ${ }^{5}$ It has been shown to have a wide margin of safety and a broad therapeutic index. Furthermore, it diffuses rapidly across the capillary wall into the central nervous system and can be mixed with saline or glucose solutions to allow its administration as a continuous infusion. ${ }^{6}$

\section{Subjects and methods}

Twenty children suffering from status epilepticus admitted to the paediatric ward from November 1993 to November 1995 were included in this study. Eleven were already taking various antiepileptic drugs.

Status epilepticus was diagnosed according to the criteria of Engel, namely continuous seizures for 30 minutes or longer or several seizures occurring with impairment of consciousness between seizure activity. ${ }^{2}$ Refractory status epilepticus was the diagnosis if the seizures continued, despite at least two doses of diazepam intravenously or rectally in succession followed by phenytoin sodium/ phenobarbitone or both $20 \mathrm{mg} / \mathrm{kg}$ given over 30 minutes as an infusion, or failure to respond to the latter alone or in combination. The duration of status before midazolam therapy was approximate, based on the history obtained from the patient's attendants and the referring physician's notes. Electroencephalography (EEG) was not used for the diagnosis. It was, however, performed after the seizures had been controlled to monitor the electrical suppression of seizure discharge. Continuous EEG monitoring was not available. However, it was used to diagnose non-convulsive status epilepticus at onset. All children underwent computed tomography scanning of the brain and other relevant investigations.

All 20 children received intravenous midazolam at $0.15 \mathrm{mg} / \mathrm{kg}$ as a bolus followed by a constant infusion starting at $1 \mu \mathrm{g} / \mathrm{kg} / \mathrm{min}$ up to $5 \mu \mathrm{g} / \mathrm{kg} / \mathrm{min}$ increasing by $1 \mu \mathrm{g} / \mathrm{kg} / \mathrm{min}$ every 15 minutes until complete control of seizures was achieved. The optimum rate of infusion at which seizure control was achieved was maintained for a period of 24 hours. Subsequently the midazolam infusion rate was gradually decreased (by $1 \mu \mathrm{g} / \mathrm{kg} / \mathrm{min}$ every two hours) until tapering was completed.

Variables such as age, weight, sex, history of seizures, underlying diseases, and the time required for control of seizures were carefully recorded for each patient. Vital parameters 
Table 1 Type, duration, and control of status epilepticus

\begin{tabular}{|c|c|c|c|c|c|c|c|c|c|c|c|}
\hline \multirow[b]{2}{*}{ No } & \multirow[b]{2}{*}{ Age } & \multirow[b]{2}{*}{ Sex } & \multirow[b]{2}{*}{ Diagnosis } & \multirow[b]{2}{*}{$\begin{array}{l}\text { Previous } \\
\text { antiepileptic drugs }\end{array}$} & \multicolumn{3}{|l|}{ Status } & \multicolumn{3}{|c|}{ Midazolam } & \multirow[b]{2}{*}{ Outcome } \\
\hline & & & & & Type & $\begin{array}{l}\text { Duration } \\
\text { (minutes) }\end{array}$ & $\begin{array}{l}\text { Antiepileptic } \\
\text { drugs received to } \\
\text { control }\end{array}$ & $\begin{array}{l}\text { Rate } \\
(\mu \mathrm{g} / \mathrm{kg} / \\
\mathrm{min})\end{array}$ & $\begin{array}{l}\text { Cessation } \\
\text { of seizures } \\
\text { (minutes) }\end{array}$ & $\begin{array}{l}\text { Side } \\
\text { effects }\end{array}$ & \\
\hline 1 & 2 months & $M$ & $\begin{array}{l}\text { Acute purulent } \\
\text { meningitis }\end{array}$ & Nil & GTC & 40 & $\begin{array}{l}\text { DZP PR, IV, } \\
\text { PHT IV }\end{array}$ & 1 & 15 & Nil & $\begin{array}{l}\text { No } \\
\text { recurrence }\end{array}$ \\
\hline 2 & 10 years & M & Idiopathic epilepsy & $\begin{array}{l}\text { SVA, VGB, } \\
\text { LTG, PHT, } \\
\text { ETH }\end{array}$ & GTC & 45 & DZP PR, IV & 1 & 30 & Nil & $\begin{array}{l}\text { No } \\
\text { recurrence }\end{array}$ \\
\hline 3 & 10 years & $\mathrm{F}$ & Idiopathic epilepsy & - & GTC & 30 & PHT IV & 1 & 15 & Nil & $\begin{array}{l}\text { No } \\
\text { recurrence }\end{array}$ \\
\hline 4 & 4 years & $\mathrm{F}$ & $\begin{array}{l}\text { Neurological } \\
\text { degeneration }\end{array}$ & SVA & $\begin{array}{l}\text { Partial } \\
\text { motor/MYO }\end{array}$ & 300 & DZP PR & 2.5 & 50 & Nil & Several \\
\hline 5 & 1 year & M & $\begin{array}{l}\text { Postencephalitic } \\
\text { sequalae }\end{array}$ & PHT, PHB & GTC & 180 & DZP IV (3) & 2.5 & 60 & Nil & $\begin{array}{l}\text { No } \\
\text { recurrence }\end{array}$ \\
\hline 6 & 2 months & $M$ & $\begin{array}{l}\text { Cerebrovascular } \\
\text { accident }\end{array}$ & SVA, PHT & GTC & 120 & DZP IV & 1.5 & 25 & Nil & $\begin{array}{l}\text { No } \\
\text { recurrence }\end{array}$ \\
\hline 7 & 6 months & $M$ & $\begin{array}{l}\text { Acute purulent } \\
\text { meningitis }\end{array}$ & - & GTC & 45 & $\begin{array}{l}\text { DZP IV, PHT } \\
\text { IV }\end{array}$ & 1.5 & 25 & Nil & $\begin{array}{l}\text { No } \\
\text { recurrence }\end{array}$ \\
\hline 8 & 8 months & $M$ & $\begin{array}{l}\text { Acute purulent } \\
\text { meningitis }\end{array}$ & - & Partial motor & 60 & $\begin{array}{l}\text { DZP IV, PHB } \\
\text { IV }\end{array}$ & 1 & 25 & Nil & $\begin{array}{l}\text { No } \\
\text { recurrence }\end{array}$ \\
\hline 9 & 5 years & M & $\begin{array}{l}\text { Chronic } \\
\text { encephalitis }\end{array}$ & SVA, CLZ & GTC, MYO & 1440 & $\begin{array}{l}\text { DZP PR, IV, } \\
\text { PHT IV }\end{array}$ & 5 & 220 & Nil & $\begin{array}{l}\text { Lost to follow } \\
\text { up }\end{array}$ \\
\hline $10^{\star}$ & 3 years & M & Idiopathic epilepsy & $\mathrm{CBZ}$ & MYO, T & 90 & DZP IV & 2 & 40 & Nil & $\begin{array}{l}\text { No } \\
\text { recurrence }\end{array}$ \\
\hline 11 & 3 years & $M$ & Idiopathic epilepsy & - & MYO, astatic & 30 & DZP PR & 1 & 10 & Nil & $\begin{array}{l}\text { Recurred } \\
\text { twice }\end{array}$ \\
\hline 12 & 13 years & $M$ & $\begin{array}{l}\text { Cerebrovascular } \\
\text { accident }\end{array}$ & - & GTC & 40 & DZP IV & 2 & 60 & Nil & $\begin{array}{l}\text { No } \\
\text { recurrence }\end{array}$ \\
\hline $13^{\star}$ & 4 years & M & Idiopathic epilepsy & CBZ, SVA, CLZ & MYO, T & 120 & DZP PR (2) & 2 & 25 & Nil & $\begin{array}{l}\text { No } \\
\text { recurrence }\end{array}$ \\
\hline 14 & 9 years & $\mathrm{F}$ & Idiopathic epilepsy & SVA, CBZ & $\begin{array}{c}\text { Complex } \\
\text { partial }\end{array}$ & 65 & PHT IV & 2 & 30 & Nil & $\begin{array}{l}\text { No } \\
\text { recurrence }\end{array}$ \\
\hline 15 & 3 years & $\mathrm{F}$ & $\begin{array}{l}\text { Acute } \\
\text { meningoencephalitis }\end{array}$ & - & $\begin{array}{c}\text { Complex } \\
\text { partial }\end{array}$ & 60 & PHT IV & 2.5 & 50 & Nil & $\begin{array}{l}\text { No } \\
\text { recurrence }\end{array}$ \\
\hline 16 & 6 months & M & Cerebral dysgenesis & PHB, PHT, SVA & GTC & 720 & $\begin{array}{l}\text { DZP PR, PHT } \\
\text { IV }\end{array}$ & 5 & 240 & Nil & $\begin{array}{l}\text { Recurred } \\
\text { twice }\end{array}$ \\
\hline 17 & 3 years & $M$ & Idiopathic epilepsy & SVA, PHT & GTC, MYO & 120 & PHT IV & 2 & 60 & Nil & $\begin{array}{l}\text { No } \\
\text { recurrence }\end{array}$ \\
\hline 18 & 7 years & M & Idiopathic epilepsy & SVA, PHT & GTC & 45 & PHT IV & 2 & 60 & Nil & $\begin{array}{l}\text { No } \\
\text { recurrence }\end{array}$ \\
\hline 19 & 2 years & $\mathrm{F}$ & $\begin{array}{l}\text { Acute } \\
\text { meningoencephalitis }\end{array}$ & - & GTC & 30 & $\begin{array}{l}\text { PHT IV, PHB } \\
\text { IV }\end{array}$ & 1 & 15 & $\begin{array}{l}\mathrm{SpO}_{2} \\
\quad 90 \%\end{array}$ & $\begin{array}{l}\text { No } \\
\text { recurrence }\end{array}$ \\
\hline 20 & $\begin{array}{l}2.5 \\
\text { years }\end{array}$ & M & $\begin{array}{l}\text { Acute } \\
\text { meningoencephalitis }\end{array}$ & s & $\begin{array}{l}\text { GTC, } \\
\text { dystonic }\end{array}$ & 60 & $\begin{array}{l}\text { PHT IV, PHB } \\
\text { IV }\end{array}$ & 1.5 & 25 & $\begin{array}{l}\mathrm{SpO}_{2} \\
\quad 90 \%\end{array}$ & $\begin{array}{l}\text { No } \\
\text { recurrence }\end{array}$ \\
\hline
\end{tabular}

GTC = generalised tonic-clonic $; \mathrm{T}=$ tonic $; \mathrm{MYO}=$ myoclonic $; \mathrm{IV}=$ intravenous $; \mathrm{PR}=$ per rectum $; \mathrm{DZP}=$ diazepam; $\mathrm{PHT}=$ phenytoin sodium $; \mathrm{PHB}=$ phenobarbitone; SVA = sodium valproate; $\mathrm{CBZ}=$ carbamazepine; VGB = vigabatrin; $\mathrm{LTG}=$ lamotrigine; $\mathrm{ETH}=$ ethosuximide; $\mathrm{SpO}_{2}=\mathrm{oxygen}_{\mathrm{saturation}}$ * Lennox-Gastaut syndrome status.

including respiratory rate, heart rate, and blood pressure were documented. The oxygen saturation of each child was monitored continuously by pulse oximetry.

The children were also monitored for the development of adverse effects of benzodiazepines including hypotension, hypoxia, and respiratory depression. In order to exclude electrolyte and metabolic disturbances as a cause of the seizures, blood samples were taken on admission and at 24 hours to measure circulating sodium, potassium, calcium, glucose, and magnesium concentrations.

\section{Results}

Of the 20 children with status epilepticus admitted to our high dependency care unit, 15 were boys (table 1 ). The mean age was 4.07 years (range 2 months to 13 years). Eleven children had a history of seizures and were already taking antiepileptic drugs, which included various combinations of sodium valproate $(n=9)$, carbamazepine $(n=3)$, phenobarbitone $(n=2)$, phenytoin sodium $(n=6)$, clonazepam $(n=2)$, ethosuximide $(n=1)$, vigabatrin $(n=1)$, and lamotrigine $(n=1)$. Eight children had idiopathic epilepsy, three acute purulent meningitis, three acute meningo- encephalitis, and the remainder had various vascular or degenerative lesions of the brain.

The type of status presented in the children as follows: generalised tonic-clonic $(n=13)$, partial seizure status (partial motor $(\mathrm{n}=2)$, complex partial $(\mathrm{n}=2))$, myoclonic astatic $(\mathrm{n}=$ 1), and Lennox-Gastaut status (myoclonic + tonic; $n=2$ ). Myoclonic seizures were seen as a combination of myoclonus with generalised tonic-clonic status in three others. Twelve patients had refractory status epilepticus (table 2). Their seizures continued for more than 30 minutes after administration of diazepam, followed by phenytoin sodium/phenobarbitone or both intravenously. Eight children being followed up in the outpatient department who were on various antiepileptic drugs were given midazolam infusion alone.

Table 2 Drugs given before midazolam in refractory status epilepticus

\begin{tabular}{ll}
\hline Drug & No of cases \\
\hline Diazepam & 12 \\
IV & 9 \\
PR & 7 \\
Combined & 3 \\
Phenytoin & 11 (2 with phenobarbitone) \\
Phenobarbitone & 3 (2 with phenytoin)
\end{tabular}

$\mathrm{IV}=$ intravenous; $\mathrm{PR}=$ per rectum. 
Table 3 Control of status epilepticus with midazolam infusion

\begin{tabular}{llllllll}
\hline \multirow{2}{*}{$\begin{array}{l}\text { No of } \\
\text { patients }\end{array}$} & & \multicolumn{2}{l}{ Dose $(\mu \mathrm{g} / \mathrm{kg} / \mathrm{min})$} & & \multicolumn{2}{l}{ Time (minutes) } \\
& & Range & Mean & & Range & Mean \\
\hline Refractory status epilepticus & $12(1)$ & $1-5$ & 2.12 & & $15-240$ & 64.6 \\
Established status epilepticus & 8 & $1-2.5$ & 1.79 & & $10-60$ & 34.3 \\
& $20(1)$ & $1-5$ & 2.0 & & $10-240$ & 54 \\
\hline
\end{tabular}

Numbers in parentheses indicate numbers of patients in which seizures were not controlled.

Table 4 Dose of midazolam required to control status epilepticus and length of time required

\begin{tabular}{llll}
\hline \multirow{2}{*}{$\begin{array}{l}\text { Midazolam } \\
(\mu \mathrm{g} / \mathrm{kg} / \mathrm{min})\end{array}$} & No of patients & \multicolumn{2}{l}{ Time (minutes) } \\
\cline { 3 - 4 } & & Range & Mean \\
\hline 1 & 6 & $10-30$ & 18.3 \\
$1-2$ & 9 & $25-60$ & 43.7 \\
$2-<5$ & 3 & $50-60$ & 53.3 \\
5 & $2(1)$ & 240 & 240.0 \\
\hline
\end{tabular}

One seizure was not controlled (shown in parentheses).

Complete arrest of seizures was achieved with midazolam infusion in all but one of the 20 children (table 3 ). The non-responder had Batten's disease. The mean time taken to control status in refractory status epilepticus was 64.6 minutes (range 15-240 minutes) and in established status epilepticus, 34.3 minutes (range 10-60 minutes). However, the mean time between the start of midazolam infusion and total cessation of seizures in all patients was 0.90 hours (54 minutes). The mean infusion rate of midazolam required to control the seizures completely was $2 \mu \mathrm{g} / \mathrm{kg} / \mathrm{min}$ (range $1-5 \mu \mathrm{g} / \mathrm{kg} / \mathrm{min}$ ). Fifteen of the patients were controlled with $2 \mu \mathrm{g} / \mathrm{kg} / \mathrm{min}$ or less (table 4 ). In two of the children there was a transient fall in oxygen saturation (to $90 \%$ ), as demonstrated by pulse oximetry. However, there was no associated hypotension or change in heart rate. No active intervention was needed except oxygen by mask (2 litres/minute for two hours).

Both these children had received intravenous phenobarbitone $(20 \mathrm{mg} / \mathrm{kg})$ from the peripheral hospital three hours before transfer. All the vital parameters of the other 18 children remained well within normal limits. No child required endotracheal intubation or mechanical ventilation. The electrolyte and glucose levels were within normal limits in all the children at the time of admission and 24 hours later. All children regained consciousness at a mean time of 5.1 hours after discontinuation of the midazolam infusion.

\section{Discussion}

If normally adequate doses of diazepam, phenytoin, and phenobarbitone fail to terminate seizures in status epilepticus, the condition is then considered to be refractory. ${ }^{7}$ In a review article, Shorvon divided status epilepticus into early, established, and refractory. ${ }^{8}$ Refractory is the description if the seizures continue for 60-90 minutes after the initiation of therapy.

Midazolam, a 1,4-benzodiazepine agent of the group of 1,2-annelated benzodiazepines, is a water soluble compound which penetrates the central nervous system rapidly and has a short elimination half life of $1.5-3.5$ hours. ${ }^{9}$ It is commonly used as an amnestic and anxiolytic agent and for operative induction and sedation of critically ill patients. ${ }^{10}$ The finding of anticonvulsant efficacy in animal studies ${ }^{11}$ was followed by anecdotal reports of the success of intravenous midazolam in terminating seizures and status epilepticus in humans. ${ }^{612}$

In our study, midazolam infusion controlled seizures in all cases of established status epilepticus and 11 of 12 cases of refractory status epilepticus, giving an overall $95 \%$ success rate, which is almost equal to the results of Rivera $e t$ $a l .{ }^{13}$ One patient with refractory status epilepticus was confirmed to have Batten's disease, a progressive neurodegenerative disorder, and failed to respond. The mean rate of infusion of midazolam required to control seizures was $2.12 \mu \mathrm{g} / \mathrm{kg} / \mathrm{min}$ in refractory status epilepticus and $1.79 \mu \mathrm{g} / \mathrm{kg} / \mathrm{min}$ in established status epilepticus (table 3 ). These results are comparable with those reported for adult patients. ${ }^{12} 14$ The maximum midazolam dose given to achieve control was $5 \mu \mathrm{g} / \mathrm{kg} / \mathrm{min}$, which is much lower than the $18 \mu \mathrm{g} / \mathrm{kg} / \mathrm{min}$ used in an earlier study. ${ }^{13}$ The mean time required to control the seizure was 34.3 minutes (10-60 minutes) in established status epilepticus and 64.6 minutes (15-240 minutes) in refractory status epilepticus, which is very similar to the 0.78 hours (range 15 minutes to 4.5 hours) found by Rivera et al. ${ }^{13}$ All types of status epilepticus were treated with midazolam. The majority of our cases $(75 \%)$ were convulsive, with five cases (numbers 10,11, 13, 14 and 15, see table 1) that were non-convulsive. About $25 \%$ of cases of status epilepticus are non-convulsive, ${ }^{1516}$ and aggressive management has been recommended to terminate clinical and EEG detected seizure activities. ${ }^{16}{ }^{17}$ The mean infusion rate of midazolam required to control seizures was $1.9 \mu \mathrm{g} / \mathrm{kg} / \mathrm{min}$ and the duration was 31 minutes.

It is not clear how midazolam works, when diazepam and phenytoin/phenobarbitone have failed to control seizures. ${ }^{18}$ The more rapid rate of arrival at the receptors concerned with termination of seizures may be the critical factor. ${ }^{18}$ It acts more rapidly, is safer and more effective. ${ }^{19}$ Several other antiepileptic mechanisms of midazolam do not distinguish it from diazepam or lorazepam..$^{20}$

During the acute phase of seizure disorder, midazolam was more effective and safer for the control of seizures than comparable doses of diazepam. ${ }^{21}$ Because of the effective control of status epilepticus with midazolam, eight patients who had status epilepticus as the result of drug default were given midazolam alone to control the condition in addition to the defaulted oral antiepileptic drug (given via a nasogastric tube).

Drugs such as pentobarbitone, paraldehyde, and isoflurane have been used to treat status epilepticus with variable degrees of success. Pentobarbitone, which is commonly used in the treatment of the condition, is a general anaesthetic and its use is frequently accompanied by myocardial depression and hypo- 
tension. ${ }^{1}$ As it is a respiratory depressant, its use at high dose for the control of seizures often has to be accompanied by endotracheal intubation and mechanical ventilation. Paraldehyde, which is no longer recommended, ${ }^{22}$ has serious side effects such as pulmonary haemorrhage, pulmonary oedema, and renal and liver toxicity. Isoflurane, an inhalational general anaesthetic agent, although effective in controlling refractory seizures, produces considerable respiratory depression and muscle relaxation, often warranting endotracheal intubation and mechanical ventilation. ${ }^{23}$

Ghilain and coworkers found a $15 \%$ rate of occurrence of mild hypotension and a $10 \%$ frequency of bradycardia when $0.2 \mathrm{mg} / \mathrm{kg}$ midazolam was given intramuscularly to adult patients with seizures. ${ }^{24}$ Two children in our series developed transient mild hypoxia. As the oxygen saturation fell to $90 \%$, the children needed oxygen by mask for two hours. Without any further intervention the oxygen saturation returned to normal. The vital parameters of the remaining 18 children were well within normal limits. No child had to be intubated or mechanically ventilated, and there were no electrolyte abnormalities.

\section{Conclusion}

The results of our study using midazolam at $1-5 \mu \mathrm{g} / \mathrm{kg} / \mathrm{min}$ as a constant intravenous infusion after a bolus dose of $0.15 \mathrm{mg} / \mathrm{kg}$, substantiate the suggestion that midazolam infusion is an effective and safe therapeutic approach for the management of childhood status epilepticus including the refractory condition. It can be used alone in status epilepticus resulting from drug default. In addition, the dose of midazolam can be conveniently titrated to the requirement of each child. Adverse effects such as respiratory depression are not seen when the drug is given alone or with phenytoin. Midazolam also has the pharmacokinetic advantage over other commonly used drugs in having a shorter duration of action. We suggest that midazolam should be the drug of choice for treatment of childhood status epilepticus.

1 Firsby JR. Status epilepsy. In: OLTE, ed. Intensive care manual. Sydney: Butterworths, 1990: 266-9.

2 Engel Jr JE. Status epilepticus. In: Engel Jr JE, ed. Seizures and epilepsy. Philadelphia: FA Davis, 1989: 256-80.

3 Hauser AW. Status epilepticus: frequency, aetiology and neurological sequelae. Adv Neurol 1983;34:3-14.

4 Delgado-Escueta AV, Bajorek JG. Status epilepticus: mechanisms of brain damage and rational management. Epilepsia 1982;23:29-41.

5 Amrein R, Hetzel W. Pharmacology of Dormicum (midazolam) and Anexate (flumazenil). Acta Anaesthesiol Scand 1990;34:6-15.

6 Galvin GM, Jelinek GA. Midazolam: an effective agent for seizure epilepsy control. Arch Emerg Med 1987;4:169-72.

7 Bleck TP. Refractory status epilepticus. Neurology Chronicle 1992;2:1-4.

8 Shorvon S. Tonic clonic status epilepticus. I Neurol Neurosurg Psychiatry 1993;56;125-34.

9 Dunde JW, Halliday NJ, Harper KW, Brogden RN. Midazolam: a review of its pharmacological properties and therapeutic uses. Drugs 1984;28:519-43.

10 Reves JG, Fragen RJ, Vinik R, Greenblatt DJ. Midazolam:

pharmacology and uses. Anesthesiology 1985;62:310-24.
11 Raines A, Henderson TR, Swinyard EA, Dretechen KL. Comparison of midazolam and diazepam by the intramuscomparison of midazolam and diazepam by the intramuscular route for the control of seizures in a
status epilepticus. Epilepsia 1990;31:313-7.

12 Crisp CB, Gannon R, Knauft F. Continuous infusion of Crisp CB, Gannon R, Knauft F. Continuous infusion of
midazoalm hydrochloride to control status epilepticus. Clin midazoalm hydrochlor

13 Rivera R, Segnini M, Bactodano A, Perez V. Midazolam in the treatment of status epilepticus in children. Crit Care Med 1993;21:991-4.

14 Kumar A, Bleck TP. Intravenous midazolam for the treatment of refractory status epilepticus. Crit Care Med 1992;20:483-8.

15 Celesia CG. Modern concepts of status epilepticus. $7 A M A$ 1976;235:1571-4.

16 Cascino GD. Nonconvulsive status in adults and children. Epilepsia 1993;34(suppl 1):521-8.

17 Stores G, Zaiwalla Z, Styles E, Hoshika A. Nonconvulsive status epilepticus. Arch Dis Child 1995;73:106-11.

18 Bleck TP. Advances in the management of refractory status epilepticus. Crit Care Med 1993;21:955-7.

19 Egli M, Albani C. Relief of status epilepticus after IM administration of the new short acting benzodiazepine, midazolam (Dormicum). Abstracts of Excerpta Medica 1981;137:44.

20 Haefely W. Benzodiazepines: mechanism of action. In: Levy R, Mattson R, Meldrum B, et al, eds. Antiepileptic drugs. 3rd Ed. New York: Raven Press, 1989:721-34.

21 Domino EF. Comparitive seizure inducing properties of various cholinesterase inhibitors: antagonism by diazepam and midazolam. Neurotoxicology 1987;8:113-22

22 Browne TR. Paraldehyde, chlormethozale and lidocaine for treatment of status epilepticus. Adv Neurol 1983;34:50915 .

23 Kofke WA, Snider MT, Young RS, et al. Prolonged low flow isofluorane anaesthesia for status epilepticus. Anaesthesiology 1985;62:653-7.

24 Ghialin S, Van Ruckevorsel-Harmant K, Harmant J, et al. Midazolam in the treatment of epileptic seizures. $\mathcal{F}$ Neurol Neurosurg Psychiatry 1988;51:732-5. 